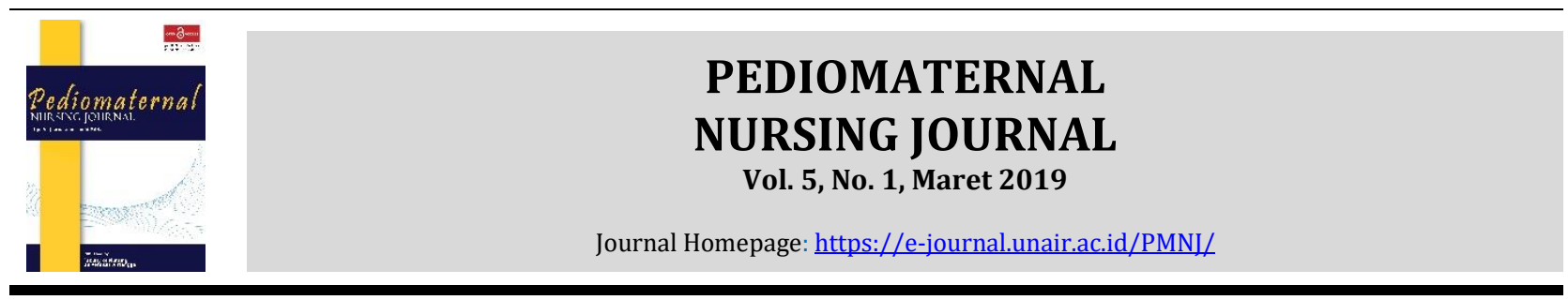

Original Research

\title{
Slime as Playing Therapy on Response of Biological, Psycological and Eating Behaviour of Preschool in Hospital
}

\author{
Maria Yasintha Seran, Ilya Krisnana, dan Praba Diyan Rachmawati
}

Faculty of Nursing, Universitas Airlangga, Surabaya, East Java, Indonesia

\section{ARTICLE HISTORY}

Received: Feb 12, 2019

Accepted: April 11, 2019

\section{KEYWORDS}

play therapy; slime; biological response; psychological response; eating behavior

\section{CORRESPONDING AUTHOR}

Maria Yasintha Seran maria.yashinta.seran2017@fkp.unair.ac.id Faculty of Nursing, Universitas Airlangga, Surabaya, East Java, Indonesia

Cite this as:

\begin{abstract}
Introduction: Slime is one of the toys that many kids like because it was adorable with a variety of bright and colorful color variations. The purpose of this study was to determine the effect of slime play therapy on biological, psychological, and eating behavior in preschool children who undergo hospitalization in the Dahlia Room of RSUD Mgr. Gabriel Manek, SVD Atambua.

Methods: This research used quasi experiment with post-test only non-equivalent control group design. The total population was 90 patients with a sample size of 60 respondents, divided into 30 treatment groups and 30 control groups. The sample was determined by consecutive sampling technique. The independent variable was slime play therapy. The dependent variable was biological, psychological, and eating behavior. Data were obtained by observation sheet and Child Eating Behavior Questionnaire (CEBQ) instrument and data were analyzed by the Mann-Whitney U Test.

Results: There were differences between the treatment group and the control group on respiratory frequency $(\mathrm{p}=0.021)$, pulse frequency $(\mathrm{p}=0.002)$, stress $(\mathrm{p}=0.035)$, and eating behavior $(\mathrm{p}=0.041)$.

Conclusion: Slime play therapy was an atraumatic care approach that can be used to reduce stress level hospitalization, biological responses to normal, and eating behavior to be good for children who were hospitalized.
\end{abstract}

Seran, M. Y., Krisnana, I., \& Rachmawati, P. D (2019). Slime as Playing Therapy on Response of Biological, Psycological and Eating Behaviour of Preschool in Hospital. Pediomaternal Nurs. J., 5(1), 17-24.

\section{INTRODUCTION}

The main stressors of hospitalization include separation, loss of control, bodily injury, pain and the most experienced is a decrease in even loss of appetite during hospital treatment that can affect biological responses (eating behavior, pulse and respiration rate) and psychological (stressed hospitalization) (1). Decrease or loss of appetite in preschool children can be caused by several factors, such as the hospital environment, menus provided by the hospital and the absence of play facilities for children (2). During the treatment process, children need to play as a medium to reduce stress hospitalizes and stimulate an increase in appetite in preschool children who are hospitalized (1). Therapy plays in the Dahlia Room of the RSUD MGR. Gabriel Manek, Atambua SVD, has never been done before.

The National Center for Health Statistics reports that 3-5 million children under 6 years of age were hospitalized and stressed hospitalization and decreased appetite during hospital treatment (3). The results of the preliminary study were obtained in the Dahlia Room of the RSUD MGR. Gabriel Manek, Atambua SVD, obtained data that the number of children treated in 2017 in August - December was as many as 464 patients and in 2018 from January to March as many as 90 patients. Data obtained from RSUD Mgr. Gabriel Manek, Atambua SVD that in 2018 children who experienced a decrease in appetite by $79 \%$ and the majority of preschool children who were treated experienced stress, often cried and did not 
want to eat food from hospitals and food bought by parents outside the hospital.

Nurses and parents in caring for and providing care for children who are cared for at the hospital are required to be able to provide stimulating educational and interesting games (4). One of the games that is very popular with children is the slime game. For children, playing slime is a fun activity that can train sensory, motoric, and child psychology development. The slime game can also reduce stress levels in children. The benefits of slime games include making children feel happier, as a means of channeling children's emotions themselves, increasing children's concentration, means of self-expression for children, saturated release facilities that are effective for children, making children more creative, and improving their children's abilities (5). When preschool children were happy and the effects of the euphoria of slime play will cause a large amount of energy to be used in the child's body, the body will provide a stimulus to the hypothalamus with a hungry sensation (6).

The hypothalamus is a part of the brain that plays an important role in regulating homeostasis processes, including regulating behavior and appetite (7). The hypothalamus accepts neural, endocrine and metabolic signals, then integrates and uses various effector pathways to cause behavioral, autonomic and endocrine responses. In addition, the central regulation of appetite and energy balance also involves the nervous system extensively covering the brain stem, cerebral cortex, olfactory area, and hormones (8). Ghrelin is one of the hormones, namely peptides with 28 amino acids which can cause an increase in food intake and reduce the use of fat reserves. Ghrelin stimulates the eating breath through the feeding center in the hypothalamus (9).

Play needs for children are very important, especially for children who are undergoing treatment at the hospital. Playing is an activity that can stimulate the growth and development of children both physically and psychologically (10). Through playing all aspects of a child's development it is grown so that the child becomes healthier and smarter. Playing in pre-school children has been shown to improve mental development, intelligence, gross motoric and fine motor skills (4). Children's thinking is stimulated to utilize their emotional, social, and physical aspects. Slime games are in accordance with the cognitive development of pre-school age children (11). The game is done using media tools and materials in the process of making slime. Slime can be made in various kinds of colorful containers and included in small, shaped molds that are attractive to children. During the process of making and playing using slime children will feel happier, and can produce hormone endorphins which can make children's moods become happier and can increase appetite (5).

\section{METHOD}

\subsection{Design}

The research was a type of quasi experiment research with a post-test only non-equivalent control group design approach.

\subsection{Population, sample, and sampling}

The population in this study were all children treated in the Dahlia Room of Mgr. Gabriel Manek, SVD Atambua Hospital in January - March as many as 90 children. The sample in this study were 60 patients with a division of 30 in the treatment group and 30 in the control group and using purposive sampling.

\subsection{Variables}

The independent variable in this study was slime play therapy. The dependent variables in this study were biological response (frequency of respiration rate and pulse), psychological response (stress hospitalization) and feeding behavior of preschool children.

\subsection{Instruments}

Child psychology response instruments during hospitalization, using check list observation sheets based on theory (Wong, 2008), that consists of 4 indicators: 1). The result of separation consists of 4 questions, 2). As a result of losing control consisting of 4 questions, and due to bodily injury consisting of 4 questions. Yes score $=1$, no $=0$. If the value is $\geq 75 \%$ $($ score $\geq 9)=$ maladaptive, and $<75 \%$ (score $<9)=$ adaptive.

The Child Eating Behavior Questionnaire (CEBQ) consists of 35 items consisting of 8 subscales, 1) food responsiveness (FR), 2) enjoyment of food (EF), 3) the desire to drink (DD), 4) satiety responsiveness (SR), 5) slowness in eating (SE), 6) food business (FF), 7) emotional overeating (EOE), 8) emotional undereating (EUE). Each category consists of 3-6 items of questions. In practice, parents are asked to assess the eating behavior of their children using the Linkert scale (never, rarely, sometimes, often, and always). CEBQ which has been translated into Indonesian and tested the validity and reliability using Cronbach's Alpha. Based on Cronbach's Alpha test, the coefficient value was 0.605 .

Pulse instruments use standard operational procedures for measuring vital signs with normal values. Pulse in pre-school children 65-110 times per minute score used $0=$ abnormal, $1=$ normal.

The respiration rate instrument uses the standard operational measurement of respiration rate or respiration. Normal value of respiration rate in preschool children 20-25 times per minute (1) score used $0=$ Normal, $1=$ abnormal. 


\subsection{Analysis}

This study was analyzed using the Mann Whitney U Test with alpha 0.05

\subsection{Ethical Clearance}

This study has conducted a health research ethical test at the Health Research Ethics Commission of the Faculty of Nursing, Airlangga University with number 1210-KEPK on December 10, 2018.

\section{RESULT}

Distribution of respondents according to demographic characteristics in the treatment and control groups with a total of 60 children. The age of children in the majority treatment group was 3 years as many as 12 children (40\%) and in the control group the majority of children were 4 years as many as 10 children (33.3\%). The majority of the sexes in the treatment and control groups were women with a total of 18 children (60\%). The majority of respondents in both groups had a history of being treated in the hospital as much as 1 time, namely in the treatment group as many as 25 children (83.3\%) and controls as many as 26 children $(86.7 \%)$. The majority of children in both groups were guarded by mothers and all respondents in both groups had good relationships with their families. The majority of children in the treatment group underwent treatment in the hospital for 7 days, and in the control group was 8 days [Table $\mathbf{1}$ ].

In the treatment group all respondents (100\%) had a pulse in the range of the normal category (65$110 \mathrm{x} / \mathrm{m}$ ), namely in the treatment group as many as 30 children $(100 \%)$ while in the control group the majority were in the normal range of 27 children (90\%) But still 3 children (10\%) found the pulse range to be abnormal (below 65-110 bpm). The results of data analysis in the treatment and control groups showed that there were differences in the results in the two groups carried out using the MannWhitney U Test ( $\mathrm{p}=0.021)$ [Table 2].

In the treatment group the majority of respiratory frequencies were in the normal category $(20-25 \mathrm{x} / \mathrm{m})$, which were 26 children (86.7\%). However, in the

Table 1. Distribution of Respondents According to Demographic Characteristics in the Dahlia Room of Mgr. Gabriel Manek, SVD Atambua Hospital in December 2018-January 2019

\begin{tabular}{|c|c|c|c|c|}
\hline \multirow{2}{*}{ Characteristics } & \multicolumn{2}{|c|}{ Treatment Group } & \multicolumn{2}{|c|}{ Control Group } \\
\hline & $\mathbf{n}$ & $\%$ & $\mathbf{n}$ & $\%$ \\
\hline \multicolumn{5}{|l|}{ Age of child } \\
\hline 1. 3 years & 12 & 40 & 6 & 20 \\
\hline 2. 4 years & 7 & 23.3 & 10 & 33.3 \\
\hline 3. 5 years & 8 & 26.7 & 8 & 26.7 \\
\hline 4. 6 years & 3 & 10 & 6 & 20 \\
\hline Total & 30 & 100 & 30 & 100 \\
\hline \multicolumn{5}{|l|}{ Gender } \\
\hline 1. Male & 12 & 40 & 12 & 40 \\
\hline 2. Female & 18 & 60 & 18 & 60 \\
\hline Total & 30 & 100 & 30 & 100 \\
\hline \multicolumn{5}{|l|}{ Experience being treated in a hospital } \\
\hline 1. 1 time & 25 & 83.3 & 26 & 86.7 \\
\hline 2. 2 times & 5 & 16.7 & 4 & 13.3 \\
\hline Total & 30 & 100 & 30 & 100 \\
\hline \multicolumn{5}{|l|}{ Families who look after children in hospitals } \\
\hline 1. Mother & 22 & 73.3 & 19 & 63.3 \\
\hline 2. Father & 6 & 20 & 8 & 26.7 \\
\hline 3. Grand Father & 1 & 3.3 & - & - \\
\hline 4. Baby sitter & 1 & 3.3 & 3 & 10 \\
\hline Total & 30 & 100 & 30 & 100 \\
\hline \multicolumn{5}{|l|}{ Child relationship with family } \\
\hline 1. Good & 30 & 100 & 30 & 100 \\
\hline Total & 30 & 100 & 30 & 100 \\
\hline \multicolumn{5}{|l|}{ Children are treated with a diagnosis: } \\
\hline 1. Dengue fever & 6 & 20 & 5 & 16.7 \\
\hline 2. Gastroenteritis & 5 & 16.7 & 4 & 13.3 \\
\hline 3. Malaria & 5 & 16.7 & 4 & 13.3 \\
\hline 4. Pneumonia & 5 & 16.7 & 6 & 20 \\
\hline 5. Asthma & 3 & 10 & 4 & 13.3 \\
\hline 6. Anemia & 6 & 20 & 7 & 23.3 \\
\hline \multicolumn{5}{|l|}{ Long treated at the hospital } \\
\hline 1. 6 days & 9 & 30 & 3 & 10 \\
\hline 2. 7 days & 11 & 36.7 & 7 & 23.3 \\
\hline 3. 8 days & 7 & 23.3 & 15 & 50 \\
\hline 4. 9 days & 3 & 10 & 5 & 16.7 \\
\hline Total & 30 & 100 & 30 & 100 \\
\hline
\end{tabular}


control group most respiratory frequencies were abnormal (below 20-25 x/m), which were 13 children (43.3\%). The results of data analysis in the treatment and control groups showed that there were differences in the results in the two groups carried out using the Mann-Whitney U Test $(\mathrm{p}=0.002)$ [Table 3].

In both groups the majority of children's psychological responses were adaptive, namely in the treatment group as many as 25 children (83.3\%) and in the control group as many as 19 children (63.3\%). But most of the respondents in the non-adaptive control group were 11 children $(36.7 \%)$. The results of data analysis in the treatment and control groups showed that there were differences in the results in the two groups carried out using the Mann-Whitney U Test ( $\mathrm{p}=0.035)$ [Table 4]. is an activity that can stimulate the growth and development of children both physically and psychologically (12).

Through playing all aspects of a child's development it is grown so that the child becomes healthier and smarter. Playing in pre-school children has been shown to improve children's mental development and intelligence (13). The main stressors experienced from hospitalization include separation, loss of control, bodily injury, pain and can affect biological responses such as pulse rate, respiratory frequency and eating behavior (1).So that play facilities in the form of play therapy, can be given by nurses to children who are undergoing treatment at the hospital. The purpose of playing at the hospital in principle is so that children can adapt more effectively to stress. Slime is one of the games that

Table 2. Distribution of the Pulse Rate of Respondents in the Treatment and Control Groups in the Dahlia Room of Mgr. Gabriel Manek, SVD Atambua Hospital in December 2018-January 2019

\begin{tabular}{|c|c|c|c|c|}
\hline \multirow{2}{*}{ Pulse } & \multicolumn{2}{|c|}{ Treatment Group } & \multicolumn{2}{|c|}{ Control Group } \\
\hline & $\mathbf{N}$ & $\%$ & $\mathbf{N}$ & $\%$ \\
\hline Normal & 30 & 100 & 27 & 90 \\
\hline Abnormal & - & - & 3 & 10 \\
\hline Total & 30 & 100 & 30 & 100 \\
\hline Mean & \multicolumn{2}{|c|}{101.6} & \multicolumn{2}{|c|}{92.8} \\
\hline Std. Deviation & \multicolumn{2}{|c|}{8.088} & \multicolumn{2}{|c|}{15.624} \\
\hline Mann-Whitney U Test & \multicolumn{4}{|c|}{$p=0.021$} \\
\hline
\end{tabular}

Table 3. Respondent Respiratory Frequency Distribution of Treatment and Control Groups in Dahlia Room of Mgr. Gabriel Manek, SVD Atambua Hospital in December 2018-January 2019

\begin{tabular}{lccccc} 
& \multirow{2}{*}{ Respiration rate } & \multicolumn{2}{c}{ Treatment Group } & \multicolumn{2}{c}{ Control Group } \\
& $\mathbf{N}$ & $\mathbf{0}$ & $\mathbf{N}$ & $\mathbf{\%}$ \\
\hline Normal & 26 & 86.7 & 17 & 56.7 \\
Abnormal & 4 & 13.3 & 13 & 43.3 \\
Total & 30 & 100 & 30 & 100 \\
Mean & & 21 & & & 19.47 \\
Std. Deviation & & 1.838 & & 2.063 \\
Mann-Whitney U Test & & & $\mathrm{p}=0.002$ & \\
\hline
\end{tabular}

In the treatment group more than half of respondents had good eating behavior as many as 19 children (63.3\%) and in the control group the majority of eating behavior was less than 17 children $(43.3 \%)$. The results of data analysis in the treatment and control groups showed that there were differences in the results in the two groups carried out using the Mann-Whitney U Test ( $\mathrm{p}=0.041)$.

\section{DISCUSSION}

The results of the study on pulse frequency showed that there were differences in the results of biological pulse responses between the treatment and control groups. In the treatment group all respondents' pulses were normal after being given intervention with slime play therapy. Children who undergo hospice will experience stress that can cause abnormal pulse. By giving play therapy, children will feel happy and entertained which will have a positive effect on the normal pulse of the respondent. Playing many kids like because it is chewy and adorable with a variety of bright color variations (14).

Slime can be made in containers with various colors and inserted in small prints so that it is attractive to children. kids love slime because it is chewy and adorable. For children, playing slime is a fun activity. Children are very happy if they buy tools for slime making by their parents. Playing slime helps children learn while playing, can increase appetite for children where children eat while playing. Playing slime is also good for training psychological and motoric development for children (15). Playing slime can relieve stress, when a child is sick and is hospitalized. As a game to make the mood in children and fun so it stimulates the child's desire to eat for a faster healing process. Based on research, it turns out playing colorful games can activate a person's brain system. Playing slime will also make children think and imagine, creativity and innovate in making toys for themselves (16). 
Children will feel comfortable and happy and not feel like they are in a hospital. The treatment room for children must be supported by an adequate environment and in accordance with developments in children undergoing treatment. Play facilities need to be provided as children's media to play, because one stage of development in children is by playing. When children play, hormone endorphins will be stimulated, so the child will feel happy and the pulse will be regular.

The results of the distribution of research in the control group showed that there were respondents with abnormal pulses. The respondent was once known to have been treated in hospital twice. The control by seeking freedom of movement, maintaining a child's routine and encouraging children to be independent. Positive adaptation can make coping and positive behavior so that child anxiety can be lowered (1).

The results of the study on respiratory frequency showed that there was an effect of slime play therapy in the treatment and control groups. The distribution of data showed that in the treatment group the majority of respondents' respiration rate frequency was normal. Play can be used as a tool to reduce stress and anxiety associated with hospitalization in preschool age children. The intended play is a therapeutic play and the importance of family

Table 4. Distribution of Psychological (Stress) Respondents in Treatment and Control Group Respondents in the Dahlia Room of Mgr. Gabriel Manek, SVD Atambua Hospital in December 2018-January 2019

\begin{tabular}{|c|c|c|c|c|}
\hline \multirow{2}{*}{ Psychological Response (stress) } & \multicolumn{2}{|c|}{ Treatment Group } & \multicolumn{2}{|c|}{ Control Group } \\
\hline & $\mathbf{N}$ & $\%$ & $\mathbf{N}$ & $\%$ \\
\hline Adaptive & 25 & 83.3 & 19 & 63.3 \\
\hline Maladaptive & 5 & 16.7 & 11 & 36.7 \\
\hline Total & 30 & 100 & 30 & 100 \\
\hline Mean & \multicolumn{2}{|c|}{$\begin{array}{c}3.1 \\
3.827\end{array}$} & \multicolumn{2}{|c|}{5.37} \\
\hline Std. Deviation & & & & \\
\hline Mann-Whitney U Test & \multicolumn{3}{|c|}{$p=0.035$} & \\
\hline
\end{tabular}

Table 5. Feeding Behavior Distribution of Respondents in the Treatment and Control Groups in the Dahlia Room of the Mgr. Gabriel Manek, SVD Atambua Hospital in December 2018-January 2019

\begin{tabular}{lccccc}
\hline & \multirow{2}{*}{ Eating Behavior } & \multicolumn{2}{c}{ Treatment Group } & \multicolumn{2}{c}{ Control Group } \\
& $\mathbf{N}$ & $\mathbf{0}$ & $\mathbf{N}$ & $\mathbf{\%}$ \\
\hline Good Eating Behavior & 19 & 63.3 & 13 & 56.7 \\
Less eating behavior & 11 & 36.7 & 17 & 43.3 \\
Total & 30 & 100 & 30 & 100 \\
Mean & & 4.8 & & & 4.2 \\
Std. Deviation & & 1.472 & & 1.095 \\
Mann-Whitney U Test & & & $\mathrm{p}=0.041$
\end{tabular}

author argues that these respondents experienced hospitalization stress which can be seen from the abnormal biological response of the pulse. Respondents who had undergone hospital hospitalization with frightening experiences that made children become traumatized will cause recurring fears, so that children can experience stress hospitalization which can be seen from irregular pulse frequency, children crying easily, and fear when nurses or doctors come to check the patient's condition.

Efforts to prepare children and families to face hospitalization can be given nursing intervention, namely minimizing psychological stressors for family members and preparing children before being admitted to the hospital. The nurse has great responsibility during the treatment process. Care provided aims to cure children physically, physiologically and psychologically as well as children's perceptions of their illness (17).

Nurses must understand that their care is familycentered and nurses use verbal and non-verbal communication according to the child's developmental level. Minimizing the feeling of losing involvement to participate in minimizing the impact of hospitalization on children (18).

When child coping becomes positive by accepting invasive actions it will be biologically responded through the HPA axis pathway that affects the neuroendocrine system. Neural and endocrine pathways under the control of the hypothalamus. First there is a decrease in CRF (corticotropin Releasing Factor) secretion, then followed by a decrease in medullary adrenal sympathetic secretion wherein this gland will produce small amounts of catecholamine. If catecholamines are produced in small amounts, vasoconstriction will occur in peripheral blood vessels so that it can reduce heart rate or pulse and stabilize respiratory frequency (19).

Distribution data in the treatment group showed that there were still some responses with abnormal respiratory frequencies. In children with anemia, severe respiration rate is also fast due to lack of oxygen to all organs of the body. If the oxygen supply decreases, even oxygen intake will be less as the compensation is shortness of breath. Meanwhile, children treated with a diagnosis of pneumonia cause the child's respiratory frequency to be abnormal. 
Based on the results of observations carried out by researchers, all children given slime play therapy showed happy and not fussy expressions while undergoing treatment at the hospital.

The child's reaction in overcoming the hospitalization crisis is influenced by the level of development of age, previous experience with the disease process and being treated at home in the hospital, the support system available, the seriousness of the disease and coping skills in dealing with stress. Gender can also influence a child's response to hospitalization. At all age levels reviewed as a group, boys, they will find it more difficult to make adjustments to something new compared to girls. Poor health conditions, anxiety, and anxious environment will increase children's emotionality (20). Play therapy can be a solution that can be applied to both groups, namely the treatment group and the control group. Status and conditions of respiratory frequency in children are also influenced by the diagnosis of diseases suffered by children. Children diagnosed with respiratory disorders, surely the frequency of respiration rate will increase due to compensation of the body for the need for oxygen.

The results of the study on stress showed that there were differences in psychological responses among respondents between the treatment and control groups. Tabulation data shows that the majority of respondents' psychological responses to the treatment group are adaptive. The main stressors experienced from hospitalization include the result of separation from family, loss of control, bodily injury or injury, pain (1). Slime play therapy will stimulate cognitive and emotional processes where the child will release the tension and stress they experience because by playing the child can divert the pain in the game (distraction) (21). This will continue to increase the cooperative level of children and then will have positive coping and an adaptive response to the stress of hospitalization.

The cooperative level shown by the treatment group that received slime play therapy was linked to adaptation theory, Roy stated that humans are described as a system that is living, open and adaptive of changes in elements, material in the environment described as one unit which has input, control, feedback processes and output. Part of the system is the cognator and regulator subsystem. The cognator subsystem is a subsystem that is related to brain function to the process of information, decision making and emotion (22). Children are given input which is playing slime and then an information processing process will occur including the integration of new information. The process of part of the adaptation experienced by children will form an adaptive and maladaptive behavior. The response and behavior of children towards hospitalization are individual depending on the stage of child development, experience of being treated in a previous hospital, existing support systems and coping abilities possessed by children (4). Most respondents in the treatment group had more than one treatment experience. The experience of being treated becomes very influential for a child for future life.

The results of this study are in line with the research conducted (23) on Audio Recording Imagination Guidance Methods to reduce the stress of hospitalization in pre-school age children in hospitals in the city of Palu. The researcher said that the experiences of children treated beforehand would affect the child's response to hospitalization. This will give the child an idea of what they are experiencing so that they influence the child's response such as painful actions and experience in controlling the stressful conditions. In addition, the factors that make children more vulnerable to the emotional impact of hospitalization and cause children's needs to be significant, namely prior experience and introduction to medical events, length and number of hospitalizations (24).

Tabulation data in the control group showed that most respondents showed maladaptive psychological responses. This can be caused from medical actions obtained by respondents during treatment at the hospital. In other conditions the child experiences anxiety because when the action is carried out the infusion of the family or the mother cannot accompany the child, so the child appears unfriendly to the nurse, and refuses to take action. These results are in accordance with the theory revealed by (22) who said that stress can cause physical, emotional, intellectual, social, and spiritual consequences. Physically, stress threatens physiological homeostasis. Emotionally, stress produces negative or not constructive feelings or emotions. Intellectually, stress affects a person's perception and ability to deal with problems. Socially can disturb someone with other children. Spiritually can provide challenges to one's beliefs and values.

According to the researcher, in conducting medical action, the person closest to the child (such as a mother, father or brother) must be able to assist because the child will feel happy and comfortable if there is a mother beside him. So that children can adjust themselves during the process of medical action and will be more interested in the surrounding environment, want to play with other children, and be able to make new relationships with new children. The effort is intended to eliminate stress in children who want the presence of parents so they can overcome it by forming good new relationships with others.

The results of the study on eating habits showed that there were differences in eating behavior in children undergoing hospitalization between the treatment and control groups. Distribution data show that the majority of children's eating behavior in both groups is lacking. This can be caused due to the response of children during hospitalization which causes a decrease in appetite in children. Hospitalization in children can illustrate tension and is a crisis that appears to children, because children experience stress due to environmental changes, 
changes in their health status, and children have limitations in coping mechanisms. The child's reaction to these crises is influenced by the age of the child's development, the experience of the previous child, with the child's coping skills acquired and acquired, the severity of the diagnosis, and the existing support system (12). Decrease or loss of appetite in children can be caused by several factors such as the hospital environment, the menu provided which can cause children to experience stress hospitalization. Children can react to the stress of hospitalization before entering, during hospitalization, and after repatriation. The concept of pain that children have is more important than age and intellectual maturity in estimating anxiety levels before hospitalization (2).

Nurses and parents in caring for and providing care for children who are treated at the hospital are expected to provide stimulation of educational and interesting games that can make children comfortable and while undergoing hospital treatment (4). One game that is currently booming is the game of making slime. Slime can be made in containers with various colors and inserted in small prints so that it is attractive to children. Slime is one of the toys that many kids like because it is cute and has a variety of bright color variations. For children, playing slime is a fun activity that can train sensory, motoric, and child psychology development (5). In addition, the slime game can also reduce stress levels in children. The benefits of slime play include making children feel happier, as a means of channeling children's emotions, increasing children's concentration, means of self-expression for children, saturated release facilities that are effective for children, making children more creative, and improving their children's abilities. When pre-school children feel happy and the effects of the euphoria of the slime play will cause a large amount of energy to be used in the child's body, so the body will provide stimulus to the hypothalamus with a sensation of hunger (5).

The hypothalamus is a part of the brain that plays an important role in regulating homeostasis processes, including regulating behavior and appetite. The hypothalamus accepts neural, endocrine and metabolic signals, then integrates and uses various effector pathways to cause behavioral, autonomic and endocrine responses. In addition, the central regulation of appetite and energy balance also involves the nervous system extensively covering the brain stem, cerebral cortex, olfactory area, and hormones (8). Ghrelin is one of the hormones, namely peptides with 28 animo acids which can cause an increase in food intake and reduce the use of fat reserves. Ghrelin stimulates appetite through eating centers in the hypothalamus (9). This game is in accordance with the cognitive development of preschool age children (11). During the process of making and playing using slime children will feel happier, and can produce endorphin hormones that can make children's moods become happier and can increase appetite (7).
The researcher argues that when children feel happy and do not feel that they are being treated in a hospital, the child's psychological condition will remain good and not affect the child's diet. Conditions that occur at this time are indeed difficult to make the condition of caring for the hospital can make it comfortable for children. Because mistakes from parenting applied by children also provide a role that is quite influential, for example when children cry, parents will say if the child is not silent, then it will be occupied by nurses. It looks easy, but it can give a trace to the child's mind, if crying will be directed by the nurse and cause the child to be afraid of the presence of nurses. This if it lasts a long time can make children become stressed so that it affects the eating behavior of children during hospitalization at the hospital.

\section{CONCLUSION}

Slime play therapy by teaching children to make and play with new games, so that children's coping becomes positive by accepting invasive actions that will be responded biologically where the pulse, respiration rate frequency becomes normal, psychological response (stress hospitalization) decreases and children's eating behavior increases. The next researcher can apply research with different designs and provide pretest and posttest treatment by providing slime play therapy. The next researcher can also develop slime play therapy or compare the effectiveness of slime play therapy with other play therapies.

\section{ACKNOWLEDGEMENT}

We would like to thanks to Directur of Mgr. Gabriel Manek, SVD Atambua Hospital for permission and admission us to take data as material research and all of the respondents.

\section{REFERENCES}

1. Terry K, Susan C. Buku Ajar keperawatan pediatri. Edisi 2. Jakarta: EGC; 2014. 134 p.

2. Tekin G, Sezer Ö. Applicability of play therapy in Turkish early childhood education system: today and future. Procedia - Soc Behav Sci [Internet]. 2010 Jan 1 [cited 2018 Apr 19];5:50-4. Available from: https://www.sciencedirect.com/science/arti cle/pii/S1877042810014230

3. Tat F, Sing SA. Florentianus Tat*Selfiana A. Sing,. Pengaruh Ter Bermain Alat Kedokt Terhadap Perilaku Koop Dalam Asuhan keperawatan Anak Usia Pra Sekol Di Ruang Anak RSUD kefamenanu Kabupaten Timor Teng Utara . 2014;13:710-21.

4. Purnama AP. Efektivitas Penggunaan Media Video Dan Media Leaflet Terhadap Perubahan Pengetahuan Dan Sikap Siswa Tentang Bahaya Napza Di Smp Negeri 3 Mojosongo 
Boyolali. Universitas Muhammadiyah Surakarta; 2013.

5. Maharini T, Irawati, Susanti S, Salamah U, Retno S. Workshop: Pemanfaatan dan Pembuatan Alat Permainan Edukasi (APE) Pengembangan untuk Anak USia Dini dan Anak Berkebutuhan Khusus (ABK). Malang; 2017.

6. Marcus SM, Malas NM, Quigley JM, Rosenblum KL, Muzik M, LePlatte-Ogini DJ, et al. Partnerships with Primary Care for the Treatment of Preschoolers. Child Adolesc Psychiatr Clin N Am [Internet]. 2017 Jul 1 [cited 2018 Apr 19];26(3):597-609. Available from:

https://www.sciencedirect.com/science/arti cle/pii/S105649931730041X

7. Sherwood L. Human Physiology from Cells to System. 3rd ed. Cole: Brooks; 2012. 617-620 p.

8. Schwartz M, Woods S, Porte D. Central Nervous System Control of Food Intake. Nature. 2015;404:661-9.

9. Wang G, Lee H, Englande E. Ghrelin not just another stomach hormone. Regul Pept. 2002;105:392-428.

10. Diani N, Waluyo A, Sukmarini L. PENGETAHUAN KLIEN TENTANG DIABETES MELITUS TIPE 2 Pendahuluan Metode. J Keperawatan Indones. 2013;16(2):120-7.

11. Chronis-Tuscano A, Lewis-Morrarty E, Woods KE, O'Brien KA, Mazursky-Horowitz H, Thomas SR. Parent-Child Interaction Therapy With Emotion Coaching for Preschoolers With Attention-Deficit/Hyperactivity Disorder. Cogn Behav Pract [Internet]. 2016 Feb 1 [cited 2018 Apr 19];23(1):62-78. Available from: https://www.sciencedirect.com/science/arti cle/pii/S1077722914001266

12. Dian A. Tumbuh Kembang dan Terapi Bermain pada Anak. 2nd ed. Raphita, editor. Jakarta: Salemba Medika; 2013.

13. Salluh JIF, Chiche JD, Reis CE, Soares M. New perspectives to improve critical care benchmarking. Ann Intensive Care [Internet]. 2018;8(1):18-20. Available from: https://doi.org/10.1186/s13613-018-03630

14. Sandra K. Manfaat Bermain Slime. In: Terapi Bermain. Jakarta: Alfabeta; 2014.
15. Vasilyeva EN, Shcherbakov A V. Parental Roles and Types of Parentings as Determinants of a Preschooler's Emotional and Personal Wellbeing. Procedia - Soc Behav Sci [Internet]. 2016 Oct 17 [cited 2018 Apr 19];233:144-9. Available from: https://www.sciencedirect.com/science/arti cle/pii/S1877042816314057

16. Wulaningsih R. Hubungan antara Persepsi Pola Asuh Orangtua dan Kontrol Diri Remaja terhadap Perilaku Merokok di Pondok Pesantren. 2015;04(4):119-26.

17. Omaç Sönmez M, Nazik F, Erol L. Management of pain in children by paediatric nurses in Eastern Turkey. Kontakt [Internet]. 2018;20(3):e250-4. Available from: https://doi.org/10.1016/j.kontakt.2018.05.0 02

18. Kinasih RP. Nephrotic Syndrome in 2 Years Old Child. 2014;1.

19. Guyton AC, Hall JE. Buku Ajar Fisiologi Kedokteran. 12th ed. Singapore: Elsevier; 2014.

20. Sanditaria W. Adiksi Bermain Game Online Pada Anak Usia Sekolah Di Warung Internet Penyedia Game Online Jatinangor Sumedang. 2012;

21. Maree JE, Moshima D, Ngubeni M, Zondi L. On being a caregiver: The experiences of South African family caregivers caring for cancer patients. Eur J Cancer Care (Engl) [Internet]. 2018 Mar 1 [cited 2018 May 14];27(2):e12801. Available from: http://doi.wiley.com/10.1111/ecc.12801

22. Potter S. Employee Motivation, Psycology, Industri. New York: Mc. Graw Hill; 2009.

23. Masulili F, Hastono SP, Kesehatan P, Palu K, Utara P, Anak KK, et al. Metode Bimbingan Imajinasi Rekaman Audio untuk Menurunkan Stres Hospitalisasi pada Anak Usia Sekolah di Rumah Sakit di Kota Palu. 2013;17(36):61-9.

24. Llorca A, Cristina Richaud M, Malonda E. Parenting, Peer Relationships, Academic Selfefficacy, and Academic Achievement: Direct and Mediating Effects. Front Psychol [Internet]. 2017 Dec 15 [cited 2018 Mar 7];8(DEC). Available from: http://journal.frontiersin.org/article/10.338 9/fpsyg.2017.02120/full 